\title{
ADOLESCENT KNOWLEDGE INDEXES IN DETEKTIF INDIGO
}

\author{
Tengku Intan Marlina Mohd Ali \\ in_marlin@yahoo.com
}

Salinah Ja'afar

b1salina@um.edu.my

Academy of Malay Studies

University of Malaya

\begin{abstract}
Teenagers or adolescents today are more exposed to a variety of reading materials, whether produced by local or international publishers. Most of the novels revolve around the story of young love, friendship, family, school and natural life. Novels with a detective or investigation theme are also being produced to court young readers. The latter type of novels not only have their charm, but are also said to be able to hone young minds to think in-depth about current and global issues. Detektif Indigo (Indigo Detectives) is a novel in a series of detective novels written by Faisal Tehrani. It is about a group of youths calling themselves Detektif Indigo. The analysis will be using Peirce's Theory of Semiotics (1965) focusing on knowledge indexes regarding Islam, international relations, social relations and science in the novel. There are many aspects of knowledge that can be extracted from this work in order to shape young minds.
\end{abstract}

Keywords: Detektif Indigo, hero, heroism, heroic deeds, heroic age, ethnocentrism 


\section{INTRODUCTION}

Knowledge is important to human life. Between knowing, knowledge and information, there are a few distinctive features that differentiate one from another. Information refers to general facts, items of information, and news (including general announcements on notice boards). However, nowadays, in the age of information technology, knowledge from all angles or disciplines can be kept or recorded, or revealed publicly. Knowing is an essence of understanding and learning that humans possess (of course God the Almighty is the highest source of Knowledge). This means only God and humans can be considered to be knowledgeable. Even though books and computers contain all kinds of knowledge, they cannot be considered knowledgeable because knowledge relates to many aspects such as intelligence, evaluation, confidence, acceptance, development and enhancement. All of these aspects of being knowledgeable are part of human nature, and cannot be obtained by machines or inanimate objects. Knowledge can be defined as the collection of information by human which is then analyzed and recorded, and classified into different disciplines. Understanding something is a way to comprehend its the meaning using different kinds of approaches based on senses, argument, inspiration and reports (Hashim Musa, 2006:12) .

Syed Muhammad Naguib Al-Attas (1970:26) wrote about Hamzah Fansuri's teachings by introducing one passage explaining the meaning of the well-known Prophetic Tradition that "whosoever knows his self knows his Lord", which means that knowing one's inward Self is to comprehend the hidden treasure of God's Knowledge. Since His Knowledge is not separate from His Being (wujud), it is when this inward Self is known (ma'lum) through God's Knowledge ('ilm) that one can know Him. Syed Muhammad Naguib Al-Attas (1970:98) added that in Sufism, as is well known, there exists a clear distinction between the concepts of ma'rifah, knowledge through experience, and ' $i l m$, which is knowledge by inference. Al-Attas notes that "In Hamzah Fansuri this clear cut distinction between gnosis and knowledge is vividly stressed in his constituent use of Malay word kenal to translate ma'rifah and tahu to translate 'ilm throughout his writings".

People who are knowledgeable will be able to organize and plan their lives according to a purpose. Through knowledge, we are able to identify problems and finding the solutions to these problems. Adolescence is an important period in life as it is during this period that the next generation of leaders and educators are developing. This is important for the human capital 
of a nation. Various ways can be used by teenagers in gaining knowledge as a foundation for the planning of their future. One of the ways to obtain knowledge is by reading. Nowadays, there are various types of reading materials for teenagers in the form of a variety of media. The production of novels for adolescents is also increasing from day to day. Today, we can find a variety of novels for adolescents produced by famous writers. It is undeniable that the novels produced are not only intended to benefit authors and publishers but also play a role as an additional tool of knowledge for the young. Among the more popular themes of such novels is the detective or investigation theme, which is deemed to be attractive for teenage readers, as well as being educational and thus enhancing their level of knowledge.

The term "adolescent literature" refers to creative works that fulfill certain criteria. Ali Haji Majod (Talib Samat, 2003/1993:374) identified eight different criteria of adolescent literature:

(a) The main characters or minor characters are adolescents but the number of characters is limited.

(b) It involves problems of adolescence, as well as reflecting the adolescent worldview, ambitions and environment.

(c) The language is aggressive and contains some characteristics of language used by teenagers.

(d) The novel is around 150-200 pages long.

(e) Adolescent novels should contain good morals. There should be hyphotheses and solutions.

(f) The ending should have a deep impact and should aim towards the enhancement of morals and the soul.

(g) The plot should be simple. If there is a complex plot, it should revolve around a single subplot only. If there are flashbacks, there should be one or two simple flashbacks.

(h) The background should be clear and can be pictured from the aspects of culture or history.

Overall, adolescent literature can be defined as creative works written for youth between 12-21 years of age, based on the themes, plot and language used by the writer. It differs in the point of view of the reader. There is really no specific definition of adolescent literature. 
Detective novels are nothing new where adolescent literature is concerned. Beginning with the translation of the English novel for adolescents, such as the Tujuh Penyiasat series translated from The Secret Seven series of Enid Blyton, the Anak-anak Hadi series, which is a translation of The Hardy Boys series written by Franklin W. Dixon, detective novels have influenced the way of thinking and the views of the young. Today, there are detective novels for teenagers written originally in the Malay language, among which is the Detektif Indigo (Indigo Detectives) series written by Faisal Tehrani. The Detektif Indigo featured a group of youngsters who are assigned to investigate the kidnapping of the Secretary General of the Organisation of Islamic Cooperation (OIC), Professor Aslan and Dr Recep Gul, the founder of the Academy of Indigo. Many aspects of knowledge can be found in this work. This is especially important in the shaping of young minds. Various methods and means are used by the author in order to attract young readers to enjoy the story. The treatment of the subject and the author's exciting style of storytelling not only attract readers but also to some extent influence the thoughts and minds of the reader to make what is read a reference and guide in daily life.

Consequently, this paper will examine the knowledge indexes used by the author in the novel Detektif Indigo as a platform to help youth to generate knowledge by focusing on the following matters:

(i) Religion

(ii) Internationality

(iii) Social relationships

(iv) Science

\section{INDEXES}

According to Roland Barthes (1988), the world is full of symbols and usually we are not aware of these, and often regard them as natural information (Theater, 1998:173). Barthes (1988:158) also says: "The world is full of signs, but these signs do not have the fine simplicity of the letters of the alphabet, of highway signs, or Military Uniforms: they are infinitely more complex". Logically, the reader has to identify the signs and then try to explain the meanings, which are cultural, social or emotional. In his study of signs, Barthes opens a new area for study, that is, the role of the reader (Paul Cobley \& Litza Jansz, 1998:51). 
Julia Kristeva (1980) has pointed out that semiotics is a very wide field that can be applied to all fields of study. Semiotics is a general field that studies the symbolism from all areas of human life. Peirce $(1965: 228)$ emphasizes:

A sign ... is something which stands to Somebody for something in some respect or capacity. It addresses Somebody, that is, creates in the mind of that person an equivalent sign, or perhaps a more developed sign. That sign which it creates I call the interpretant of the first sign. The sign stands for that object, not in all respects, but in reference to a sort of idea, which I have sometimes called the ground of represantamen.

For instance, in Peirce's model, the word "STOP" on a signboard against a red background at a junction of two roads is a signal. The word "STOP" means motorists must stop at this place. Its sign is the "STOP"; the object is the road users; represantamen is the idea of a sign which refers to the object (Daniel Chandler, 2000). When the object sees a "STOP" sign, the thinking is that he should stop at the place where the sign is located. The example given above is that of a concrete sign, which is visible to the sign receiver. Signs are not only something concrete because signs can also consist of abstract things. They may consist of something that exists within the imagination or something that cannot be imagined. Everything that can be visualized can also be a sign (Daniel Chandler, 2000:22-23): "every thought is a sign" (Daniel Chandler, 2000:253). Peirce also said, "Of course, nothing is a sign unless it is interpreted as a sign" (Daniel Chandler, 2000).

In Peirce's semiotic analysis, there are three factors that determine the sign which is the sign itself, the marked sign, and a new sign that occurs in the mind of the recipient. Between signs and marked signs there are the related representation (presenting sign). Both sign and marked sign will bear the interpretation in the mind of the recipient. The result of this interpretation is a new sign created by the recipient (Suwardi Endraswara, 2003:65). From the above explanation, it is clear that semiotics is a branch of knowledge that is unconditional and wide. However, signs play an important role in human life. Through signs, people think and communicate. Communication will only run smoothly when the recipient truly understands the signs sent by the sender.

In order to understand index in Peirce's semiotics, it is important to distinguish the differences between sign in indexes and the other concept of sign such as icons and symbols that he included in the theoretical 
description. Sign is not classified as an object. Sign exists only in the minds of interpreters (Winfried North, 1990:42). For Peirce (1965:242), signs may be identified through the process of semiosis in three categories: first comes the representamen, then the object, and finally the interpretant.

Where sign is concerned, the relationship is triangular (triadic) and genuine (Peirce, 1965:274), and can be described as follows:

\section{Interpretant}

\section{Representamen}

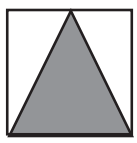

Object

Figure 1 Peirce's semiotic triangle.

For Peirce, the true meaning of signs is to produce something, also called the "denotatum" (Panuti Sudjiman \& Aart van Zoest, 1996:7). What is produced by the sign, which is pointed to, is called "object" by Peirce, and also can be described with the word "denotatum" or "designatum" (Panuti Sudjiman \& Aart van Zoest, 1996).

In the first stage of the sign, which is representamen, signs are divided into three types, namely qualisign, sinsign and legisign. In the second stage, the object, sign is divided into icons, indexes and symbols. Finally, at the third level, which is the interpretant, sign is divided into rheme, dicent signs and arguments.

The emergence of sign can be seen as follows (Panuti Sudjiman \& Aart van Zoest, 1996:31):

Table 1: The emergence of signs.

\begin{tabular}{|l|c|c|c|}
\hline Level & Firstness & Secondness & Thirdness \\
\hline Representament & Qualisign & Sinsign & Legisign \\
\hline Firstness & & & \\
\hline Object & Icon & Index & Symbol \\
\hline Secondness & & & \\
\hline Interpretent & Rheme & Dicent Sign & Argument \\
\hline Thirdness & & & \\
\hline
\end{tabular}


On the second stage, which is that of object, Peirce formulated three types of signs: icons, indexes and symbols. Icons are signs that refer to objects which show the same characteristics as described (Peirce, 1965: 247). It is the sign in relation to certain objects for similarity (Paul Cobley \& Litza Jansz, 1998:33), or in other words, the relation between the sign with signifier is equivalent to natural means (M.Si Alex Sobur, 2003:41).

An iconic sign is when there is a resemblance in appearance between the sign and the thing it represents. In the icon, the relationship between sign and object is materialized as "equality" or "similarity" that is revealed by the appearance of signs. A diagram, map or drawing has an iconic relationship with the objects, to the extent of the similarity in both (Kris Budiman, 1999: 49), and it brings certain functions relating to the interpretation of the meaning on the surface structure (Sahlan Mohd. Saman, 1994:26). Therefore, the similarity or resemblance is in the form or function (Hashim Musa, 1994:45). So, if the icon is similar to the form of the object in performing, it functions as a marker, if of a sign, it is a signifier. For instance, Imrah is an icon in Ombak Bukan Biru (The Waves are not Blue) (1979), The Missing Piece (2005), and The Missing Piece II (2006), all works written by Fatimah Busu that show the woman as an icon who is persistent, diligent, and has a strong will in her life which is full of challenges. Diligence and a strong spirit which appear in the character of Imrah are the functions of the sign, (Tengku Intan Marlina Tengku Mohd Ali, 2007:161)

Index refer to the object, which shows the effect of the object (Peirce, 1965:248). With indexes, we can establish a link between sign and its signifier with the attributes such as reality, consequences, and cause, and it often signals something (Puji Santosa, 1993:12). Mana Sikana (in June 2001:202) says that index is a sign that refers to a mark which combines a group of signs or a number of phenomena; the causes, symptoms, signs, ties and so forth. In Arus (Current) (1981) by Anwar Ridhwan, the index of Imah being eaten by a crocodile can be visualized through a river of red and Imah shouting for help. This index becomes true when the dead body of Imah is found with both of her legs broken due to her having been devoured by crocodiles.

Symbol is a sign that refers to the object, which refers to the rule (law), usually a combination of general ideas (Peirce, 1965:249), therefore, symbol is a kind of sign that is arbitrary and conventional. Thus, symbol is the equivalent to the meaning of "sign" as given by De Saussure. The term "symbol" is common to many people and widely used with diverse meanings (Kris Budiman, 1999:109). 
Symbol is a type of the sign that has some features that indicate a relationship between the sign and denotatum, which is determined by a regulation that occurs in general (Aart van Zoest, 1993:25) or can be interpreted as a sign relating to a particular object due merely to convention (Paul Cobley \& Litza Jansz, 1998:33). The relation between sign and denotatum is a relationship formed by convention (Panuti Sudjiman \& Aart van Zoest, 1992:9), and does not reflect the natural relationship between sign and signifier. From there we can say that relationship is arbitrary in nature and based on the conventions of society (Rachmat Djoko Pradoppo, 1993:121-22). The tractor in Ranjau Sepanjang Jalan (No Harvest but a Thorn) is used by Shahnon Ahmad as a symbol of modernity. The tractor is a machine that represents the scientific and technological progress which enables the farmers to work on their paddy fields twice a year. The head of the village is the only person who can afford to use a tractor for harvesting rice, while the poor farmers such as Lahuma and Jeha are still using the traditional methods to harvest rice. By using the word "tractor" the writer successfully relates technology with wealth.

Based on the description of the icon, index and symbol above, this paper discusses the application of the knowledge indexes used by the author in improving knowledge of children and teenagers in the novel Detektif Indigo by focusing on the knowledge indexes regarding Islam, international relations, social relations and science.

\section{INDEXES KNOWLEDGE RELATED TO ISLAM}

Unity is a universal human need and is demanded by any religion. Every human being aspires to live peacefully, safely, prosperously and happy forever.

One of the main reasons the Apostles of God were sent was to preserve unity among the people. The main mission of the Prophet was to unite people. The success of the Prophet to unite people in the faith is one of the most historic events in the development of Islamic civilization. The main cause that create disunity among Muslims people is due to the ignorance of the Qur'anic teachings and not living in accordance to the Sunnah. (Assoc. Prof. Daud Mustapa, http://bulitenalhikmah.blogspot.com/2007/04/puncapenyakit-perpecahan-umat-islam.html). Muslims can be united and should not be split among one another. Disunity of Muslims in the world is touched upon by the author of these novels to encourage adolescent readers to think about the situation of Muslims in the world. Professor Aslan is an icon created 
by the author for this purpose. Not coincidentally, the Professor's name is similar to that of the Russian President.

As narrated in the novel, many Muslims in live in the midst of chaos and war. For example, the people of Chechnya want to break away from Russia and create their own territory. This fact has been included in the novel so that teen readers may gain knowledge of what has happened there. This is highlighted by the author through the icon of the Russian President, a character who is based on a real person, President Aslan Maskhadov, who says in the novel:

"Kami boleh memahami jika ada orang Chechen mahu berpisah dari Rusia, budaya dan agama kami berlainan. Tetapi sekarang ada kumpulan keras dan ekstrim tertentu yang sudah masuk ke wilayah Chechen. Orang Arab. Mereka meracuni pejuang pemisah."

("We can understand if there are Chechens who want to break away from Russia, we have a different culture and religion. But then there are certain extreme and aggressive groups, which have entered into Chechen territory. Arabs. They poison the minds of the rebels.")

(Faisal Tehrani, 2008: 23).

Through the indexes "Russia" and "Chechnya", Detektif Indigo invites the reader to think about the upheaval that has occurred in the province Chechnya, as its people strive for independence from Russia.

The author also views discrimination and oppression of Muslims by Muslims themselves, i.e, by highlighting the icon "Saddam Hussein". Teen readers may remember the dictator of Iraq who has been overthrown. Saddam Hussein is shown by the writer as a Muslim who is willing to kill other Muslims, and he highlights the brutality index of Saddam Hussein in Detektif Indigo through the following passage:

Dalam sejarah dunia, Saddam Hussein, diktator Iraq pernah membunuh orang sunni Kurdish di Halabja dan orang syiah yang ramai di Iraq. Dia juga pernah menceroboh dan menawan Kuwait dalam tahun 1990.

(In world history, Saddam Hussein, the dictator of Iraq, is responsible for the killing of Kurdish Sunnis in Halabja and many Shi' ites in Iraq. He also invaded and conquered Kuwait in 1990.)

(Faisal Tehrani, 2008: 24) 
In the passage above, the information about the icon "Saddam Hussein" provides knowledge to youths about Saddam Hussein, while all the icons on the indexes are the acts he committed, including fighting against the U.S. forces and conquering Kuwait.

In addition, young readers are brought to see the split among Muslims due to differences of doctrine since ancient times among many sects. Thus, the author includes his view that it is high time Muslims ignore the sectarian differences, and be united as brothers to strengthen the close relationship that can bring mutual benefit to Muslims around the world. The author calls for Muslims to forget the religious strife, as shown in the following passage:

\begin{abstract}
Bapa Hassan dan Husin bernama Jawad berasal dari Najaf. Ibunya pula berasal dari Fallujah. Bapanya orang Islam bermazhab syiah sementara ibunya pula orang Islam bermazhab sunni. Tidak dapat dinafikan ada perselisihan antara ibu bapa mereka tetapi bukan dalam persoalan agama, sebaliknya mereka bertengkar dalam memutuskan bagaimana untuk merawat anak mereka Hasan dan Husin yang ganjil sekali tingkah laku, tidak suka bercampur orang dan boleh berbahasa Jerman secara tiba-tiba entah kerana dirasuk jin atau memang budak-budak itu berbakat.
\end{abstract}

(Hasan and Husin's father was named Jawad and he was from Najaf. Their mother was originally from Fallujah. The father was a Shiite while the mother was a Sunni. No doubt there were disagreements between them but not in the question of religious practices, rather regarding treatment of their children, Hasan and Husin, who behaved oddly, did not like to mix with people, and suddenly could converse in German, either because they were possessed by a jinn, or they really did have a special talent.)

(Faisal Tehrani, 2008: 35)

Indexes of knowledge concerning Islam show that the reader can understand the unity between the Muslims even though they are from different schools of thought, through the icons Shia and Sunni, which are tied by the author through the symbol of marriage between the parents of Hasan and Husin. Sunni is an index of the Sunnah, which is the second source of Islamic law after the Qur'an. The position and function of the Sunnah is as a complement to the Holy Qur'an. The Sunnah Wal Jamaah is a group of Muslims who adhere to the Qur'an, the Sunnah, and the consensus opinion of the Companions. Shia is an index of the icon of all the people who are faithful (wala ') to 'Ali bin Abi Talib and his Ahl al-Bait radhiallahu 'anhum, 
until it became the title of a specific name for them. The split between Sunnis and Shias is the real cause of the weakness of Muslims in the world. In the novel, the author displays the indexes of his ambition to see Muslims united. Indexes of such knowledge play a major role in among the youth towards the formation of a civilized race of people that hold to the teachings of religion, especially for Muslims. Such knowledge may equip young people better for the future.

\section{INTERNATIONAL KNOWLEDGE INDEXES}

"International" is a term that refers to a matter involving two or more countries. An index of international knowledge can be defined as an index of knowledge regarding countries other than one's own. In the case of Malaysia, for example, the index of international knowledge can be considered to be related to matters or events that occur outside Malaysia. In Detektif Indigo, the index of international knowledge is evident through a number of incidents and events associated with current issues in the international arena. The following excerpt would be an example of this:

"Pada tahun 1986 bola yang digunakan diberikan nama ezteca, iaitu di Mexico juga. Bila di Itali dalam tahun 1990 mereka guna bola sepak yang bernama etrusco, di Amerika Syarikat dalam tahun 1994 bola yang dimainkan dinamakan pula pula questra. Pada Piala Dunia di Peranchis dalam tahun 1998 FIFA memperkenalkan bola lain iaitu tricolore yang tahan disepaksepak sebab ada lapisan sintetik berbentuk silang. Piala Dunia pertama kali di Asia dalam tahun 2002 pula menggunakan bola bernama fevernova yang lapisan sintetiknya lebih sempurna.

("In 1986 the ball used was given the name "Ezteca", and in Mexico as well. In Italy in 1990, they use the ball called Etrusco, in the United States in 1994, the ball played was called "Questra". At the World Cup in France in 1998, FIFA introduced another ball which was kick-resistant called "Tricolore" because of its cross-shaped synthetic layer. In the First World Cup in Asia in 2002, the ball used was one called "Fevernova" and it had stronger synthetic layers.)

(Faisal Tehrani, 2008: 70)

The World Cup is an item of general knowledge related to the international knowledge index, while the names given to the ball also may not be known 
to all teenagers. The author has inserted new elements in order to increase reader's vocabulary and indirectly to enhance their knowledge. The following are other examples to this effect:

Mereka bergerak pulang ke makmal yang disediakan oleh tentera diraja Thailand di Narathiwat.

(They returned to the laboratory provided by the Royal Thai Army in Narathiwat.)

(Faisal Tehrani, 2008:158)

Tan Sri Ahmad Itam menjelaskan sesuatu kepada wartawan, "Penjenayah tersebut sedang diburu dan kita telah meminta bantuan Interpol." "Ini kes kita, tapi beri pada Interpol pula." Husin geram.

(Tan Sri Ahmad Itam explained to a reporter, "The criminals are being hunted down and we have asked Interpol for assistance." "This is our case, but they give to Interpol." thought Husin, resentful.

(Faisal Tehrani, 2008:168)

Within the knowledge index of world history there are the international events that could be considered as bringing knowledge to teenagers regarding events from around the world. The mention of Interpol, the international police, is another example. So is the indexical use of events in Thailand.

Indexes of international knowledge will expose adolescents to the issues of the outside world. The indexes are closely related to world peace, as well as the economic and political strength of a country. Such a knowledge index is important for adolescents in order to prepare them as future leaders who need to face the challenges of globalization.

\section{SOCIAL RELATIONS}

Malaysia's multi-racial society needs a better system concerning social relations in order to maintain the unity and peace among all the people. Social relations between different communities in terms of race, class, and social organization requires every citizen to have a better understanding about interaction, which requires a help in building a harmonious country. Each member of society 
should be familiar with the various stages of human development. Understanding of good social relationships is very important for youth in order to create the next generation of leaders and also in guiding the young to cooperate among themselves, even though they may be from different races.

Social interaction prepares the young for community life. Social relationships begin from Kindergarten level and continue until the children become adults. At the level of adolescent development, they need other people to meet their personal needs. This can be seen in the novel Detektif Indigo, where the author has included elements of social relations. Although almost all the characters in this novel are Muslim, the author also includes characters who come from different ethnic backgrounds. This shows that even if they are from different races, when placed under one roof to collaborate, each character can play their respective roles and work together in solving problems. Among the social relations that can clearly be seen in this novel are cooperation and teamwork, and interaction between boys and girls.

\section{COOPERATION AND TEAMWORK}

Cooperation requires a group of two or more people to join together in doing something to achieve a particular purpose. In order to achieve the goal or purpose intended, it is important that the members in the group mutually understand on another. The author suggests that before performing a task, each member in the group should know the others. This can be seen in the excerpt below:

"Baik, kita tak ada waktu yang banyak untuk berkenalan..." Dr. Mama memulakan bicara. "Tapi taaruf penting Dr. Mama, kami nak bekerja secara rapat nanti." Mihrimah Maryam menekankan perkataan "rapat".

("Well, we do not have much time to get acquainted ..." Dr. Mama began. "But the most important is getting to know each other, Dr. Mama, then only we can work together closely." Mihrimah she stressed the word "closely".

(Faisal Tehrani, 2008:61)

"Betul juga Dr. Mama, kalau tak saling kenal susah pula nak bekerjasama secara intim." Dendy menyahut gesit.

("That's right Dr. Mama, if we do not know one another, it is difficult to work together closely. "Dendy responded quickly.)

(Faisal Tehrani, 2008:61) 
Although cooperation is a pillar of this novel, the author does not use the word cooperation as a sign but the author describes the working relationship through the use of the forms of words like bekerjasama (cooperate), berkenalan (acquainted), taaruf (become familiar), and intim (close) instead.

Teamwork is very important for an organization in implementing a plan. Each institution of a successful organization requires all members to work together as a united group. Implementation of this group work requires leaders and members who can cooperate with each other. At the "teamwork" level, we can identify the leadership characteristics and the level of collaboration between each member. In the novel, the author describes a situation where each team member is assigned a certain role in one team headed by a leader. Through the characters portrayed, it is seen that Dendy is a teenager who has leadership qualities. Dendy is capable of taking responsibility and he is capable of controlling his team members and and dividing the tasks among them. Dendy is described as a good person, good-looking and firm in carrying out his assigned duties.

Dendy's leadership talent can be seen after he is entrusted to be the leader in the investigation of the kidnapping of Professor Aslan, when he calls on all members of the group to get to know each other and to have further discussions on the task given:

"Den, awak akan menjadi ketua untuk misi ini. Hati-hati, dan ingat bersatu kita kuat, bercerai kita roboh.” Pengetua terus memberi kata semangat. Dendy pantas berjalan diikuti tiga sahabatnya. Mereka masuk ke bilik persendirian detektif. Semua mengambil tempat duduk. Meletakkan fail-fail yang diterima di atas meja.

Dendy memberi salam, "Sebelum kita ke Sepang, saya rasa kita sendiri perlu jelas sesama kita, akan tugas masing-masing. Kita berkenalan secara ringkas dan saya mau membahagi tugas."

("Den, you will be the leader for this mission. Be careful, and always remember that united we stand, divided we fall." The Principal said, giving support and encouragement. Dendy walked quickly, followed by his three friends. They went into the detectives' private office. All took a seat and put the files they had received on the table. Dendy gave a greeting and said, "Before we go to Sepang, I think we need to be clear about our tasks. Let's introduce ourselves briefly and then I want to assign the tasks.")

(Faisal Tehrani, 2008) 
Cooperation is a very important aspect, and it is necessary that youngsters understand that in today's world everyone should help each other in order to reach their goals and achieve success. This will foster a family spirit in an institution. This family spirit is important for success or failure. Based on the depiction of cooperation and teamwork, youngsters are also shown the importance of good leadership in ensuring that any task is carried out properly.

\section{INTERACTION BETWEEN BOYS AND GIRLS}

At the adolescent stage, youngsters are learning to interact with the opposite sex outside their own family. Through peer influence, they will also be exposed to a variety of decisions that may affect their future. At this point, teenagers will be influenced by thoughts and emotions in making decisions. At this stage, adolescents also develop self-esteem.

Interaction between boys and girls is also featured in Detektif Indigo. However, the author does not go into too much detail concerning boy-girl relationships. There are a few instances showing teenage emotions and thoughts about the opposite sex. This can be seen in the following passage:

Apabila Dendy melangkah masuk ke dalam mesyuarat di Maktab Rendah Remaja Indigo Sepang, Mihrimah Maryam menyiku Rabiah Zaitun. "Aku punya Tun." Mihrimah Maryam berbisik halus.

(When Dendy walked into the meeting in Sepang Indigo Youth Junior College, Mihrimah Maryam elbowed Rabiah Zaitun. "He is mine Tun." Mihrimah whispered softly.)

(Faisal Tehrani, 2008:58)

Wajah Dendy yang damai menggugat hatinya sejenak tadi, kini amat dibenci.

Dendy's calm face, which had stirred her heart earlier, now became hateful to her.

(Faisal Tehrani, 2008:87)

Mihriam Maryam menjengul kepala sedikit dan memberitahu dengan nada rendah "Abang Den..." Dendy menoleh "Hati-hati." Dendy senyum, memekarkan lesung pipit dan mengenyit mata sebelah kiri. Mihrimah Maryam senyum malu-malu, sempat terpacul dari mulutnya "Uh...comel." 
(Mihrimah Maryam raise her head a bit and told with a low tone "Den ..." Dendy looked "Be careful." Dendy' smile revealed his dimples, and he winked his left eye. Mihrimah Maryam smile shyly, and, without realizing, said "Uh ... cute.")

(Faisal Tehrani, 2008:103)

Teenagers are the most easily influenced and misled by social interaction. It is very important to expose teenagers carefully to boy-girl relationship issues in order to avoid the things that can lead teens to social problems such as drug problems, premarital sex, illegal abortion and other things that can contribute to moral decay. Although the author does not go into the details of boy-girl relationships, there are several instances involving feelings and interaction between boys and girls in the narrative, indicating a healthy sense of shyness in members of both sexes, and that this sense of shyness or embarassment is the basis of moral strength that young people need in their daily interactions with the opposite sex.

\section{KNOWLEDGE OF SCIENCE}

Science is important to human life, especially in the modern world. Knowledge of science can be obtained not only specifically in schools but also can be obtained by reading. Novels that include actual science fact are not new in the world of children's literature but not many Malay-language novels written by local authors are able to impart scientific knowledge. In Detektif Indigo, the author has included elements of science and technology in his narrative.

Among the scientific knowledge included by the author in this novel are some instances related to with medical science, for example, forensic science:

Mereka langsung ke makmal forensik di mana Inspektor Syed Waisal meninggalkan mereka berdua.

(They went directly to the forensic laboratory where Inspector Syed Waisal left both of them.)

(Faisal Tehrani, 2008:195)

Faruq dan Mihrimah Maryam mulai meneliti lapis-lapis plastik yang telah membalut tubuh Meliha. Mihrimah Maryam meneliti foto digital yang dirakam oleh penyiasat yang awal tiba di tempat kejadian.

(Faruq and Mihrimah Maryam began to examine layers of laminated 
plastic that had been wrapped around Meliha's body. Mihrimah Maryam examined the digital photo captured by the first investigators who arrived at the scene.)

(Faisal Tehrani, 2008:196)

Profesor Aslan tidak tahu, penculik telah menyuntiknya dengan fensiklidina atau PCP, sejenis hipnotik sedatif, dadah penindas sistem saraf pusat yang lazim digunakan untuk melegakan penyakit imsomnia dan tekanan.

(Professor Aslan did not know that the kidnappers had injected him with phencyclidine or PCP, a hypnotic sedative drug that suppresses the central nervous system and is commonly used to relieve insomnia and stress.)

(Faisal Tehrani, 2008:114)

"Saya tahu." Dr. Dilaysu memecah suasana hening. "Saya ada alat terapi Repetitive Transcranial Magnetic Stimulation, atau rTMS. Kami biasa gunakan di klinik untuk merawat penderita depresi. Ini produk baru dalam dunia kedoktoran saraf.". "Saya tahu, alat magnetik itu untuk gantikan dadah bupropion dan alprazolam. Bastian, teman sebilik saya yang mengambil ijazah kedoktoran di Maktab Tinggi Remaja Indigo Nilai pernah bercerita tentangnya'." Dendy menyampuk.

("I know." Dr. Dilaysu's voice broke the silence. "I have devices using Repetitive Transcranial Magnetic, or rTMS. We use these at the clinic to treat patients with depression. This is something new treating nerve diseases." "I know, the magnetic device functions to replace the drugs bupropion and alprazolam. Bastian, my roommate who is a medical student at the Indigo College of Higher Learning in Nilai has told me about it". Dendy interrupted.)

(Faisal Tehrani, 2008:142)

Faruq mencelah segera, "Hah, tahukah anda sampel air kencing Profesor Aslan mengandungi dadah kategori saikoaktif iaitu hipnotik sedatif, dan dadah ini memberi kesan ke atas proses fisiologi serta boleh merubah persepsi, tingkah laku, ragam dan cara berfikirnya. Dadah ini diharamkan oleh kerajaan Malaysia tetapi diharuskan oleh kerajaan Belanda”.

(Faruq quickly interjected, "Well, do you know Professor Aslan urine samples contain traces of hypnotic sedatives of the psychoactive category, and these 
drugs have an impact on physiological processes and can change one's perception, behaviour, moods and way of thinking? This drug was banned by the Malaysian government, but it is permitted by the Dutch government.")

(Faisal Tehrani, 2008:127)

Faruq menolak Chen-Chung ke belakang, "Cari sodium azide, lead nitrate... senyawa kimia tadi boleh menghasilkan sesuatu."

(Faruq pushed Chen-Chung to the back, "Look for sodium azide, lead nitrate ... the chemical compounds that can be used to produce something.")

(Faisal Tehrani , 2008:70)

Due to the detective theme of this novel, the author uses symbols related to medical science. The medical indexes used by the author are forensic laboratory, therapy equipment, clinic, bupropion, physiology, psychoactive drug, sedative hypnotics and alprazolam, which can increase the vocabulary of young people and indirectly also increases their knowledge. This may attract teenagers to explore the field of medical science and suggests to youngsters that science is important in life. This may inspire young people to study hard to pursue their ambitions, especially in the scientific field. The usage of scientific words may motivate youth to increase their understanding of science by referring to the dictionary or the internet to understand the terms used.

\section{CONCLUSION}

The novel Detektif Indigo is based on the theme of detective work and investigation and there is plenty of knowledge to be gained by young readers from this novel. The author has created such signs to show the reader the disunity of Muslims, international issues, social relations and science. The knowledge Index in Detektif Indigo enables young readers to be able to cultivate knowledge. Readers will use their thinking skills to understand what is actually delivered by the author in his work. The reader will be encouraged to think about the icons, indexes and symbols shown by the author in this novel. It is clear that Detektif Indigo is not just a detective story but must be viewed with greater scrutiny by young readers to look beyond the events that are depicted by the author. 


\section{REFERENCES}

Al-Quran Mushaf Malaysia dan Terjemahan, 2007 (third impression). Shah Alam, Selangor Darul Ehsan: Yayasan Restu.

Anwar Ridhwan, 1981. Arus. Selangor: Pustaka Cipta.

Barthes, Rolland. 1988. The Semiotic Challange. New York: Hill and Wang.

Chandler Daniel, 2002. Semiotics: The Basics. London: Routledge.

Cobley, Paul \& Litza Jatza Jansz, 1998. Introducing Semiotics. London: Mc Pherson's Printing Group

Faisal Tehrani, 2008. Detektif Indigo. Kuala Lumpur: Al-Ameen Serve Holdings Sdn. Bhd.

Hashim Musa, 2006. Pengantar Falsafah Bahasa. Kuala Lumpur: Dewan Bahasa dan Pustaka.

Kris Budiman, 1999. Kosa Kata Semiotika. Kuala Lumpur: Dewan Bahasa dan Pustaka.

Kristeva, Julia, 1980. Desire in Language: A Semiotic Approach to Literature and Art. Translated by Thomas Gora, Alice Jardine \& Leon S. Roudiez. London: Oxford Blackwell.

Mana Sikana, 2001. "Teori Semiotik: Tanda Bahasa dan Wacana Sastera" in Jurnal Bahasa 1 (2). Kuala lumpur: Dewan Bahasa dan Pustaka.

Mustapha Daud, 2011. "Punca Penyakit dan Perpecahan Umat Islam". http:// bulitenalhikmah.blogspot.com/2007/04/punca-penyakit-perpecahan-umatislam.html.

North, Winfried, 1990. Handbook of Semiotics. United States of America: Indiana University Press.

Omar Hashim (comp.), 2008. Siapa Sunnah Wal-Jamaah: Berlakunya Fahaman Sesat dan Penyelewengan dalam Islam. Kuala Lumpur: Al-Hidayah Publications., Peirce, Charles Sanders, 1965. Charles Sanders Peirce's Collected Papers (Vol. I \& II). Massachusett Cambridge: The Belknap Press of Harvard University Press.

Puji Santosa, 1993. Ancangan Semiotika dan Pengkajian Susastera. Indonesia: Penerbit Angkasa Bandung.

Rachmat Djoko Pradoppo, 1993. Pengkaji Puisi: Analisis Strata Norma dan Analisis Struktural Semiotik. Jakarta: GAdjah MAda University Press.

Sahlan Mohd Saman, 1994. "Dekad 1990-an Era Kematangan Kesusasteraan Melayu" dlm. Dewan Sastera Mac:65. Kuala Lumpur: Dewan Bahasa dan Pustaka.

Syed Muhammad Naguib Al-Attas, 1970. The Mysticism of Hamzah Fansuri. Kuala Lumpur: University of Malaya Press.

Suwardi Endraswara, 2003. Metodologi Penelitian Sastra: Epistemologi, Model, Teori, dan Aplikasi. Yogyakarta : Pustaka Widyatama. 
Talib Samat, 2003/1992. Menangani Penulisan Kreatif Sastera Remaja. Kuala Lumpur: Dewan Bahasa dan Pustaka.

Tengku Intan Marlina Tengku Mohd. Ali, 2007. "Teori Semiotik Peirce dan Morris: Satu Pengenalan Kaedah Analisis Sastera" dlm. Jurnal Pengajian Melayu. Kuala Lumpur: Akademi Pengajian Melayu.

Tengku Intan Marlina Tengku Mohd. Ali, "Ikon Pak Hassan dalam Hari-hari Terakhir Seorang Seniman: Satu Kajian Semiotik" dlm. Jurnal Pangsura: Jurnal Pengkajian dan Penelitian Sastera Asia Tenggara, hlm. 8-18, JulaiDisember, Bil. 25, Jil. 13, 2007.

Tengku Intan Marlina Tengku Mohd. Ali, 2009. “Antara Dua Deru: Indeksikal Tandatanda Kehidupan". Kertas kerja yang dibentangkan dalam Seminar Sasterawan Negara Arena Wati 2009 di Dewan Bahasa dan Pustaka, Kuala Lumpur.

Van Zoest, Aart, 1993. Semiotika: Tentang Tanda, Cara Kerjanya dan Apa yang Kita Lakukan Dengannya. Jakarta: Yayasan Sumber Agung. 